\title{
Vajinal Doğum Yapan Annelerin Ten Tene Temas ile İlgili Bilgi, Uygulama ve Engelleri $\infty$
}

\author{
Samiye METE ${ }^{1}$, Buse GÜLER ${ }^{2}$, Nuran Nur AYPAR AKBAĞ ${ }^{3}$
}

\section{öz}

Amaç: Bu araştırmanın amacı, vajinal doğum yapan kadınların yenidoğan ile ten tene temasları (kanguru anne bakımı) hakkında bilgilerini, uygulamalarını ve engellerini belirlemektir.

Gereç ve Yöntem: Tanımlayıcı araştırmanın örneklemini bir kamu ve bir üniversite hastanesinde vajinal doğum yapan 108 kadın oluşturmuş̧tur. Araştırmacılar tarafından oluşturulan veri formu kadınların tanıtıcı bilgilerini ve ten tene temas kavramı konusunda bilgi, uygulamalarına ve engellerine ilişkin verileri içermektedir. Veriler SPSS 15.0 programı kullanılarak değerlendirilmiş ve verilerin analizinde tanımlayıcı istatistikler ve kikare testi kullanıımıştır.

Bulgular: Kadınlar doğumdan ortalama $32.74 \pm 25.61$ dakika sonra bebeklerini kucaklarına aldıklarını ifade etmişlerdir. \%13.0'ının ten tene temas uyguladığı belirlenmiştir. Kadınların ten tene temas tanımı ve yararları konusunda on üzerinden 1.07 puan ortalaması ile düşük düzeyde bilgiye sahip oldukları saptanmıştır. Kadınların $\% 67.8$ 'si ten tene temasın uygulanmasındaki engelin nedeni olarak ilk sırada bebeğinin giyinik olmasını belirtmişlerdir.

Sonuç: Antenatal dönemde gebeler bilgilendirilmeli ve gebelerin farkındalıkları arttırılmalıdır. Bebeklerin giysileri olmadan bebeğin teninin anne tenine değmesi gerektiği anlatılmalı ve uygulamaları desteklenmelidir.

Anahtar kelimeler: Engeller, hemşirelik, kanguru anne bakımı, ten tene temas

\begin{abstract}
Information, Practices, and Barriers Regarding Skin-to-Skin Contact of Mothers Giving Vaginal Birth

Aim: This study aims to determine the knowledge, practices, and barriers of women who give vaginal birth about skin-to-skin contact (kangaroo mother care) with their newborn.

Material and Methods: The sample of the descriptive study consisted of 108 women who gave vaginal birth in a public and university hospital. The data form created by the researchers includes women's descriptive characteristics and information about skin-to-skin contact, practices, and barriers. The data were evaluated using the SPSS 15.0 program, and descriptive statistics and chi-square test were used to analyze the data.

Results: Women stated that they took their babies in their laps, on average $32.74 \pm 25.61$ minutes after birth. It was determined that $13.0 \%$ had skin-to-skin contact. It was determined that women had a low level of knowledge about the definition of skin to skin contact and its benefits, with an average of 1.07 out of ten. $67.8 \%$ of the women stated that the biggest obstacle in applying skin-to-skin contact was that their baby was dressed.

Conclusion: Pregnant women should be informed during the antenatal period, and their awareness should be increased. It should be explained that baby's skin should touch mother's skin without clothes of babies, and their practices should be supported. Keywords: Barriers, kangaroo-mother care, nursing, skin to skin contact
\end{abstract}

\footnotetext{
${ }^{1}$ Prof. Dr., İstinye Üniversitesi Sağlık Bilimleri Fakültesi Hemşirelik Bölümü, İstanbul, Türkiye, E-mail: samiyemete@gmail.com, Tel: +90 2124813688, ORCID: 0000-00023777-2456

${ }^{2}$ Araş. Gör. Dr., Dokuz Eylül Üniversitesi Hemşirelik Fakültesi, İzmir, Türkiye, E-mail: busebahitli@gmail.com, Tel: +90 2324124773, ORCID: 0000-0003-3053-5105 ${ }^{3}$ Araş. Gör., Karamanoğlu Mehmetbey Üniversitesi Sağlık Bilimleri Fakültesi Hemşirelik Bölümü, Karaman, Türkiye, E-mail: nuraypar@gmail.com, Tel: +90 3382264395, ORCID: 0000-0002-4693-2896

*Bu çalışma 02-05 Mart 2017 tarihleri arasında düzenlenen “13. Uludağ Jinekoloji ve Obstetrik Kış Kongresi” nde poster bildiri olarak sunulmuştur.

Geliş Tarihi: 21 Haziran 2019, Kabul Tarihi: 02 Kasım 2020

Atıf/Citation: Mete S, Güler B, Aypar Akbağ NN. Vajinal Doğum Yapan Annelerin Ten Tene Temas ile Illgili Bilgi, Uygulama ve Engelleri Hacettepe Üniversitesi Hemşirelik Fakültesi Dergisi 2021; 8(1): 8-15. DOI: 10.31125/hunhemsire.906905
} 


\section{GíRiş}

Ten tene temas (TTT); doğumda veya doğumdan çok kısa bir süre sonra çıplak bebeğin annenin çıplak göğsüne yüzüstü yerleştirilmesidir. Kanguru bakımı olarak da isimlendirilmektedir1-3. Doğumdan sonraki ilk 60-90 dakika anne ile yenidoğan arasında TTT'nin sağlanması için en duyarlı dönem olarak kabul edilmektedir ${ }^{4}$.

Doğum gerçekleştikten dakikalar sonra yenidoğanın anneyle temas ettirilmesi ve etkileşiminin sağlanması maternal oksitosinin pik yapmasını sağlamakta, böylece postpartum hemorajiyi önlemektedir. Ayrıca artan prolaktin ve oksitosin annedeki stresi azaltmakta ve annenin ebeveynlik duygularını geliştirmektedir ${ }^{4}$. TTT, anneyle yenidoğan arasında biyolojik bağın gelişmesine ${ }^{5}$, annelik duygusunun güçlenmesine ${ }^{4,6,7}$ ve annenin yenidoğana adaptasyonunun sağlanmasına yardım etmektedir8-10.

Dokunma, ağlama, gülme gibi davranışlar anne-bebek bağının oluştuğunu gösterir. Ancak bu göstergelerden en temel olanı emmedir ${ }^{4}$. Doğumdan sonra bir saat içinde pik yapan maternal prolaktin emzirmeyi kolaylaştırmaktadır ${ }^{8}$. Doğumdan sonra TTT annelerin kontrol duygularını geliştirmekte, kendilerine olan güvenlerini arttırmaktadır. $\mathrm{Bu}$ sonuçların emzirmeyle ilişkili olduğu tahmin edilmektedir. Doğumdan sonra bir saat içinde TTT ile yükselen fetal oksitosin emzirmenin başlatılmasını kolaylaştıran sakin ve uyanık bir durum sağlamaktadır. Anneyle bebek arasında kurulan TTT annede vazodilatasyona neden olmakta ve bebeğin ısınmasını sağlayarak hipotermiyi önlemektedir. TTT yenidoğanda stresi ve stres hormonlarını azaltarak yenidoğanın enerji tüketimini, glukoz seviyelerini, solunumunu, ağlama ve beslenme davranışlarını en iyi duruma getirmektedir ${ }^{8}$. Ayrıca yapılan sistematik derlemede TTT uygulaması ile prematür bebeklerin anne-bebek etkileşiminin arttığı ve invaziv girişimlerde ağrının azaldığı belirtilmiştir ${ }^{11}$.

TTT tıbbi bir müdahale olarak ilk kez 1977 yılında düşük doğum ağırlıklı yenidoğanlarda mortalite ve morbiditeyi azaltmak amacıyla kullanılmaya başlanmıştır. TTT sayesinde anneler, yenidoğanların ısısını koruyarak ve emzirmeyi kolaylaştırarak sağlık çalışanına ve kuvöze gereksinimi azaltmıştı ${ }^{12}$. Kadınların doğum deneyimlerini, bebekler ve ailelerinin sağılklarını olumlu etkilediği gösterildiğinden dolayı sanayi toplumlarında, annenin doğum deneyiminin gelişmesine ve bebek ile ailelerine sağladığı yararlar nedeniyle TTT'ye önem verilmektedir ${ }^{13}$. TTT'yi teşvik etmek için uygulamadaki engellerin anlaşılması önemlidir. TTT uygulanmasında fiziksel, kurumsal, kültürel, anneye ilişkin birçok engel bulunmaktadır. Personel ve hasta eğitiminin eksikliği en önemli engeller arasındadır. Ayrıca sağlık personelinin ve kurumların politikalarının da anne-bebek ayrılmasına neden olduğu belirtilmektedir ${ }^{14}$. Yirminci yüzyılın başlarında doğumdan hemen sonra anne ile yenidoğanı ayırma az rastlanan bir durum iken, daha sonra yenidoğan ile annenin ayrı odalarda tutulması yaygınlaşmaya başlamıştır. Ayrıca doğumdan hemen sonra rutin uygulamaları gerçekleştirmek amacıyla yenidoğan anneden saatlerce ayrı kalmaktadır ${ }^{4,9}$. Bu postnatal ayrılma, stres durumu yaratarak bebeğin gelişimini ve annenin davranışlarını olumsuz etkilemektedir ${ }^{4,9}$. Bir başka engel ise kadınların ten tene temas uygulaması ve yararları hakkında bilgili olmaması, toplumun bu uygulamayı uygun görmemesi, utanma gibi kültürel algılarının farklı olması gösterilmektedir ${ }^{14}$. Kadınların ten tene temas tercihlerini inceleyen bir çalışmada özel hastanede doğum yapan kadınların \%59.3'ü, devlet hastanesinde doğum yapan kadınların \%40.7'sinin ten tene teması tercih etmedikleri saptanmıştır ${ }^{15}$.

Bakım rolleri açısından değerlendirildiğinde hemşireler TTT'yi etkilemede en büyük fırsata sahip kişilerdir. Bu etki hemşirelerin hastalara verecekleri eğitimler ve uygulamaya katılmalarına izin vererek gerçekleşir ${ }^{16}$. TTT'nin gerçekleşmesi multidisipliner ekibin katılımını gerektiren bir uygulamadır. Bu nedenle tüm sağlık çalışanlarının destek ve çabaları gereklidir. Hemşireler antenatal dönemde kadınları TTT uygulaması hakkında bilgilendirmelidir. Kadınları TTT'yi talep etmeleri için cesaretlendirmeli ve uygun ortamları oluşturmalıdır. Hemşireler, TTT'nin uygulanabilmesi için sağlık ekibine hizmet içi eğitimler planlamalıdır. Ancak hemşirelerin bu rollerini yerine getirebilmeleri için kadınların TTT uygulayıp uygulamadıklarını, uygulamayanların engellerinin neler olduğunu bilmelerine gereksinim vardır. Böylece hemşireler TTT oranlarına bakarak sorunun ciddiyetini fark edebilirler. Ayrıca hemşireler, kadınların TTT uygulamaları konusundaki güçlükleri gidermeye odaklanarak TTT uygulamasının artmasına destek verebilirler. Hemşireler TTT'nin başlatılmasını sağlayarak anne-bebek bağlanmasının başlamasına katkı verebilirler.

\section{Araştırmanın Amacı}

$\mathrm{Bu}$ araştırmanın amacı, vajinal doğum yapan kadınların yenidoğan ile ten tene temasları (kanguru anne bakımı) hakkında bilgilerini, uygulamalarını ve engellerini belirlemektir.

\section{GEREÇ ve YÖNTEM}

\section{Araştırmanın Türü}

Bu araştırma tanımlayıcı tipte bir araştırmadır.

\section{Araştırma Evren ve Örneklemi}

Araştırmanın evrenini araştırmanın yürütüldüğg̈ tarihlerde bir üniversite ve bir kamu hastanesinin obstetri kliniklerinde yatan postpartum dönemdeki kadınlar oluşturmuştur. Araştırma yapılan hastaneler, İmir'in farklı bölgelerinde bulunmaları (Kuzey-Güney) ve kamu ve üniversite hastanelerini temsil ederek her sosyoekonomik gruptaki kadına ulaşmayı sağlamaları nedeniyle seçilmişlerdir. iki hastanede yıllık toplam 3065 vajinal doğum gerçekleşmektedir. Örnekleme yöntemi olarak amaçlı örneklem yapılmış, 108 kadın ile araştırma yürütülmüştür (evrenin yaklaşık \%3.5'i). Örnekleme dahil etme kriterleri; vajinal yolla doğum yapmış olma, 18 yaşından büyük olma, Türkçe anlayabilme ve konuşabilme ve okur yazar olmadır. Araştırmanın sonunda G-Power 3.1 istatistik programında çalışma durumu ve toplam bilgi puanının ten tene temas uygulanmasına etkisini gösteren kikare analiz sonuçları kullanılarak yapılan güç analizinde elde edilen örneklem gücü \%95 olarak belirlenmiştir. 


\section{Veri Toplama Araçları}

Araştırmada kullanılan veri formu literatür doğrultusunda ve araştırmacıların deneyimlerine dayandırılarak oluşturulmuştur ${ }^{4,6,15,16}$. Kullanılan veri toplama formu iki bölümden oluşmaktadır. Birinci bölüm kadınların tanıtıcı ve obstetrik özellikleri ile ilgili soruları içermektedir. Tanıtıcı özelliklerde; yaş, eğitim durumu, çalışma durumu, mesleği, sosyal güvencesi ile ilgili dört soru, obstetrik özelliklerde; gebelik sayısı, doğum sayısı, çocuk sayısı ve şimdiki doğum şekli ile ilgili dört soru yer almaktadır. İkinci bölümde ise kadınların TTT kavramı, anne ve yenidoğan açısından faydaları ile ilgili bilgileri, bebekle anne arasında TTT ile ilgili uygulamaları içermektedir. Bu bölümde üç adet kapalı uçlu soru, altı adet açık uçlu soru bulunmaktadır. TTT'nin anne ve bebek için yararlarını değerlendirmek için oluşturulan ifadelerle ilgili kadınların verdiği her doğru cevap için 1 puan, yanlış cevap için ise 0 puan verilmiştir. Maddelerin toplamından minimum 0 , maksimum 16 puan alınabilmektedir.

\section{Veri Toplama Araçlarının Uygulanması}

Veriler İzmir'de bulunan bir kamu ve bir üniversite hastanesinin obstetri kliniklerinde Şubat-Haziran 2016 tarihleri arasında yüz yüze görüşme yöntemi ile toplanmıştır. Her bir kadınla görüşme süresi ortalama 10-15 dakikadır. Haftanın iki günü ortalama 16 saat veri toplanmıştır.

\section{Verilerin Analizi}

Verilerin analizinde SPSS (15.0) programı kullanılmıştır. Kadınların tanıtıcı, obstetrik özellikleri ve TTT uygulanma durumu ve bilgi düzeyleri hakkındaki bulguları için sayı, ortalama, standart sapma, ortanca ve yüzde dağılımları yapılmıştır. TTT uygulanma durumunun kadınların tanıtıcı ve obstetrik özelikleri ile ilişkisini incelemek için kikare testi uygulanmıştır.

\section{Araştırmanın Etik Boyutu}

Araştırmanın yürütüleceği hastanelerden kurum izinleri ve Dokuz Eylül Üniversitesi Girişimsel Olmayan Araştırmalar Değerlendirme Komisyonu'ndan 11.08.2016 tarih ve 2474GOA protokol numaralı 2016/23-28 karar numarası ile etik kurul izni alınmıştır. Araştırmaya katılanların yazılı ve sözlü bilgilendirilmiş onamları alınmıştır.

\section{Araştırmanın Sınırlılıkları}

Araştırma sonuçları İzmir ilindeki iki hastane ile sınırlıdır. Araştırmada kullanılan veri toplama formunun geliştirilmesinde sadece araştırmacıların yer alması, diğer uzmanların görüşüne yer verilmemesi de araştırmanın sınırlıı̆̆ını oluşturmaktadır.

\section{BULGULAR}

Araştırmaya katılan kadınların yaş ortalamaları $27.86 \pm 6.06$ 'dır. Kadınların \%56.5'i ilköğretim mezunu, $\% 85.2$ 'si ev hanımıdır ve \%19.4'ünün sosyal güvencesinin olmadığı saptanmıştır (Tablo 1). Kadınların ortalama gebelik sayısı $2.12 \pm 1.09$, doğum sayısı $1.76 \pm 0.92$ ve ortalama çocuk sayısı $1.74 \pm 0.86^{\prime}$ dır.
Tablo 1. Kadınların Tanıtıcı Özellikleri ( $n=108)$

\begin{tabular}{|c|c|c|c|c|}
\hline Tanıtıcı Özellikler & $\mathbf{n}$ & $\%$ & $\overline{\mathbf{x}}$ & $\pm s s$ \\
\hline $\begin{array}{l}\text { Yaş } \\
18-29 \\
30-40\end{array}$ & $\begin{array}{l}63 \\
45\end{array}$ & $\begin{array}{l}58.3 \\
41.7\end{array}$ & 27.86 & 6.06 \\
\hline \multicolumn{5}{|l|}{ Eğitim Durumu } \\
\hline illköğretim & 67 & 62.0 & & \\
\hline Ortaöğretim & 26 & 24.1 & & \\
\hline Üniversite & 15 & 13.9 & & \\
\hline \multicolumn{5}{|l|}{ Çalışma Durumu } \\
\hline Çalışıyor & 14 & 13.0 & & \\
\hline Çalışmıyor & 94 & 87.0 & & \\
\hline \multicolumn{5}{|l|}{ Sosyal Güvence } \\
\hline Var & 87 & 80.6 & & \\
\hline Yok & 21 & 19.4 & & \\
\hline Toplam & 108 & 100 & & \\
\hline
\end{tabular}

Araştırmaya katılan kadınların doğumdan ortalama $32.74 \pm 25.61$ dakika sonra bebeklerini kucaklarına aldıkları belirlenmiştir. Kadınların \%13.9'unun doğumdan sonra bebeklerini kucaklarına almak istemediği bunun en önemli nedeninin de ağrı (\%46.7) olduğu belirlenmiştir. Kadınların sadece \%13'ü doğumdan sonra bebekleriyle TTT sağladığını ifade etmiştir. Kadınların \%67.8'i doğumdan hemen sonra TTT sağlanmamasının nedeni olarak bebeğin giydirilmiş olmasını belirtmişlerdir. Araştırmaya katılan kadınların \%75'inin TTT kavramını duymadığı saptanmıştır. TTT kavramını duyan kadınların \%77.8'i anne ve \%66.7'si bebek için TTT'nin yararlı olduğunu belirtmişlerdir. En çok bilinen yarar olarak kadınların \%33.3'ü annelik duygusunu geliştireceği ve \%33.3'ü bebeğin anneye bağlanmasını sağlayacağını belirtmişlerdir (Tablo 2).

Tablo 2. Kadınların Ten Tene Temas Uygulama Sıklığı, Uygulamama Nedenleri ve Yararları Konusunda Bilgileri

\begin{tabular}{|l|c|c|}
\hline Ten Tene Temas uygulama, uygulamam & & \\
nedenleri ve Yararları konusunda Bilgi & $\mathbf{n}$ & \\
\hline Ten Tene Temas sağlanma durumu (n= 108) & & \\
Hayır & 94 & 87 \\
Evet & 14 & 13 \\
\hline Ten Tene Temas kavramını duyma (n= 108) & & \\
Hayır & 81 & 75 \\
Evet & 27 & 25 \\
\hline Bebeği kucağına alma isteği (n= 108) & & \\
Evet & 93 & 86.1 \\
Hayır & 15 & 13.9 \\
\hline Bebeği kucağa almama nedenleri (n= 15) & 7 & 46.7 \\
Ağrı & 5 & 33.3 \\
Hatırlamıyor & 2 & 13.3 \\
Kendinde olmama & 1 & 6.7 \\
Kötü hissetme & & \\
\hline Ten Tene Temasın sağlanamama nedeni & & \\
(n= 59) & 40 & 67.8 \\
Bebeğin giyinik olması & 6 & 10.2 \\
Annenin giyinik olması & 4 & 6.8 \\
Bilgisinin olmaması & 6.8 \\
Anne ve bebeğin giyinik olması & 6.8 \\
Bebek bakımının yapılması & 1.7 \\
Bebeğin mekonyumlu doğması & & \\
\hline
\end{tabular}


Tablo 2. Kadınların Ten Tene Temas Uygulama Sıklığı, Uygulamama Nedenleri ve Yararları Konusunda Bilgileri (devamı)

\begin{tabular}{|l|c|c|}
\hline $\begin{array}{l}\text { Ten Tene Temas uygulama, uygulamam } \\
\text { nedenleri ve Yararları konusunda Bilgi }\end{array}$ & $\mathbf{n}$ & $\%$ \\
\hline $\begin{array}{l}\text { Ten Tene Temasın anne için yararları (n= 27) } \\
\text { Annelik duygusunu geliştirme }\end{array}$ & 9 & 33.3 \\
$\begin{array}{l}\text { Annelik duygusunu geliştirme ve emmeyi } \\
\text { kolaylaştırma }\end{array}$ & 9 & 33.3 \\
Kavramı duymasına rağmen bilgisi yok & 6 & 22.2 \\
$\begin{array}{l}\text { Emmeyi kolaylaştırma } \\
\text { Kanamayı azaltma, annelik duygusu geliştirme, } \\
\text { süt oluşumu, emmeyi kolaylaştırma }\end{array}$ & 1 & 7.4 \\
\hline $\begin{array}{l}\text { Ten Tene Temasın bebek için yararları (n= 27) } \\
\text { Kavramı duymasına rağmen bilgisi yok }\end{array}$ & 9 & 33.3 \\
$\begin{array}{l}\text { Bebeğin anneye bağlanmasını sağlar } \\
\text { Ruhsal gelişimi, anneye bağlanmayı sağlar, kalp } \\
\text { atışını düzenler }\end{array}$ & 4 & 33.3 \\
$\begin{array}{l}\text { Ağlamayı azaltır, solunum, vücut ısı, kan } \\
\text { şekerini düzenler, daha iyi emmeyi, ruhsal } \\
\text { gelişimi, anneye bağlanmayı olumlu etkiler }\end{array}$ & 3 & 11.2 \\
$\begin{array}{l}\text { Ruhsal gelişimini sağlar } \\
\text { Ağlamayı azaltır, emmeyi, ruhsal gelişimi ve } \\
\text { anneye bağlanmayı sağlar }\end{array}$ & 1 & 3.7 \\
\hline
\end{tabular}

Kadınların TTT uygulaması konusundaki bilgi puan ortalamalarının 1.07 \pm 2.18 (Min: 0 , Maks: 10) olduğu belirlenmiştir (Tablo 3).

Tablo 3. Annelerin Ten Tene Temas Uygulaması Bilgi Puanları* $(n=108)$

\begin{tabular}{|l|c|c|c|c|c|}
\hline & $\overline{\mathbf{x}}$ & $\mathbf{\pm S S}$ & Min & Maks & Medyan \\
\hline $\begin{array}{l}\text { Anne için } \\
\text { yarar puanı }\end{array}$ & 0.51 & 1.063 & 0 & 6 & .000 \\
\hline $\begin{array}{l}\text { Bebek için } \\
\text { yarar puanı }\end{array}$ & 0.55 & 1.313 & 0 & 6 & .000 \\
\hline $\begin{array}{l}\text { Toplam } \\
\text { bilgi puanı* }\end{array}$ & 1.07 & 2.186 & 0 & 10 & \\
\hline
\end{tabular}

*Bilgi puanından alınabilecek maksimum puan $16^{\prime}$ dır.

Araştırmada TTT uygulanma durumunun kadınların tanıtıcı ve obstetrik özellikleri ile ilişkisi değerlendirilmiştir. Çalışan kadınların (\%42.9), primiparların (\%64.3) ve TTT konusunda bilgi puanı ortalamanın üstünde olanların (\%28.6) TTT uygulama oranlarının daha yüksek olduğu bulunmuştur. Yaş gruplarının ( $p=0.567)$, TTT duymuş olmanın $(p=0.333)$, eğitim süresinin $(p=0.853)$, sosyal güvencenin $(p=1.000)$, , doğum sayısının ( $p=0.222$ ) ve sahip olunan çocuk sayısının $(p=0.073)$ TTT uygulamasına etkisinin olmadığı belirlenmiştir. (Tablo 4).

\section{TARTIŞMA}

Araştırmada vajinal doğum yapan kadınların, doğum sonunda TTT kavramı ve yararları konusundaki bilgisi ve TTT'nin uygulama durumu hakkındaki görüşleri incelenmiştir. Kadınların sadece \%13'ünün bebekleri ile TTT uyguladığı ve bu kavramı sadece \%25'inin daha önceden duyduğu saptanmıştır. Yılmaz-Esencan ve arkadaşlarının
(2018), özel ve devlet hastanesinde gebe eğitim okuluna katılmış ve eğitim almış gebelerin doğum şekli, ilk emzirme zamanı ve TTT uygulamalarını değerlendirdikleri çalışmalarında kadınların \%53.3'ünde TTT'nin sağlanmadığı saptanmıştır ${ }^{15}$. Etiyopya da yürütülen araştırmada da postpartum dönemde ten temasının uygulanma oranı \%28.1 olarak belirtilmiştir ${ }^{17}$. Annelerin sürece hazır olmaması, uygulama konusundaki bilgi yetersizliği TTT'nin gerçekleştirilmesini engelleyebilmektedir. Bu nedenle sağlık çalışanlarının, kadınların bilgilenmesini sağlayarak TTT'yi uygulama protokollerine göre uygun zamanda ve biçimde TTT uygulamasının gerçekleştirilmesini sağlamaları gerekmektedir. Gebelik süresince etkili doğuma hazırlık eğitimleri ile annelerin uyumları kolaylaştırılarak TTT uygulamaları arttırılabilir.

Mevcut araştırmada TTT'nin anne tarafından sağlanamama nedenleri değerlendirildiğinde çoğunlukla bebeğin giydirilmiş olması gerekçe gösterilmiştir. TTT bebeğin genellikle dik pozisyonda, çıplak ya da sadece bebek bezi ile annenin çıplak tenine konması olarak tanımlanmaktadır ${ }^{2,3}$. $\mathrm{Bu}$ nedenle bebeklerin giydirilmiş olarak annelerine verilmesi, kadınların TTT uygulamalarına engel olan bir uygulamadır. Araştırmamızdaki kadınların eğitim düzeyinin yetersiz olması ve sağlık personelinin zaman kısıtıılı̆ı TTT'nin tam anlamıyla gerçekleştirilmesini olumsuz etkilemiş olabilir. Bu durumda sağlığı koruma ve geliştirmede primer rol alan sağlık personelinin TTT uygulama engellerinin araştırılması önemlidir. Bu sonuçlar doğrultusunda sağılı çalışanlarına verilecek kişisel ve hizmet içi eğitimler engellerin ortadan kaldırılmasına yönelik hazırlanmalıdır.

Bu araştırmadaki kadınların \%86.1'i doğumdan hemen sonra bebeklerini kucaklarına almak istediklerini belirtmişlerdir. Kadınların \%87'si bebeklerinin rutin bakımlarından sonra bebekleri giydirilmiş olarak kucaklarına verildiğini ifade etmişlerdir. 'Annelik içgüdüseldir'18 kavramından yola çıkılarak TTT'nin kadınların annelik duygusunu artırdığı belirtilmektedir ${ }^{6}$. Bu nedenle kadınların en kısa sürede bebeklerini kucaklarına almak istemelerinin olumlu bir destek olacağı düşünülmektedir. Ancak bebeklerin giydirilmiş olarak annelerine verilmesi istenen şekilde TTT uygulanması için bir engel oluşturmaktadır. Finigan ve Davies'in (2004) İngiltere'de doğum sonundan 28. güne kadar geçen sürede kadınlarla yapılan kalitatif görüşmelerde TTT sonrasında kadınların bebeklerine daha çok bağlandıkları ve içgüdüsel bir duygu ile bebeklerini bırakmak istemedikleri belirtilmektedir. Preterm yenidoğanın yoğun bakımda kalma süresini etkileyen faktörlerin değerlendirildiği bir araştırmada kanguru bakımının annelerin kontrol duygusunu geliştirdiği ve onların bebekleriyle birlikte olma motivasyonlarını güçlendirdiği belirtilmiştir ${ }^{5}$. Ancak yukarıda da belirtildiği gibi araştırmamıza katılan kadınlara TTT uygulamasının yetersiz olduğu belirlenmiştir. Bu durum anne bebek bağlanmasını olumsuz olarak etkileyebilir.

Doğum sonrasında bebeklerini kucağına almak istemeyen kadınların en çok ifade ettikleri neden ağrılarının olmasıdır. Vajinal doğumun iyileşme sürecinin hızlı olmasına ve annebebek etkileşiminin erken başlamasına çok fazla katkısı 
olmasına rağmen perine travmalarına bağlı ağrı sık gelişen bir durumdur. Kadınların çoğunluğunun ilk 24 saatte perineal ağrı yaşadıkları belirtilmektedir ${ }^{19,20}$. Epizyotomi uygulaması ve kontrolsüz laserasyonlar nedeni ile doğum sonrası yaşanan ağrılar bebeklerini kucaklarına almak istememelerine neden olabilmektedir. Ancak Byaruhanga, Bergström, Tibemanya, Nakitto ve Okong'un (2006) yürüttükleri odak grup görüşmesi çalışmasında TTT sonrasında bazı kadınların postpartum ağrılarının azaldığı belirtilmektedir21. Ayrıca kadınların süreç içinde bebeği incitme korkusu, yorgunluk, uyku sırasında kanguru pozisyonunu korumada zorlanma, anne sütünün aşırı artması konusundaki endişeler, destek eksikliği ve sağlık personeli tarafından olumsuz tutumlar yaşadıkları belirtilmektedir ${ }^{14}$. Mevcut araştırmaya katılan kadınların TTT hakkında yetersiz bilgiye sahip olmaları ve ağrı yönetimi konusunda cesaretlendirilmemiş olmaları süreci olumsuz etkilemiş olabilir. TTT kavramının yararları konusunda bilgilendirilen kadınların annelik içgüdüsünün de yardımı ile bebeklerini kucaklarına almalarının kolaylaşacağı düşünülmektedir.

Doğum sonrasında bebeğin giydirilmesi, annenin teninin açılmaması, bebek bakımının yapılması adına bebeğin anneden uzaklaştırılması (acil durumlar dışında) gibi nedenler sağlık personelinin planladığı ve yürüttüğü süreçlerdir. Alenchery ve arkadaşlarının (2018) TTT uygulamasını engelleyen ve kolaylaştıran durumları değerlendirmek amaçlı yürüttükleri kalitatif araştırmada da sağlık personelinin klinik rutinlerinin yoğunluğu TTT sağlamada ve sürdürmede engel olarak belirtilmiştir22. Uluslararası Kanguru Anne Bakımı toplantısının (The International Network on Kangaroo Mother Care (KMC)) raporuna göre hemşireler için en yaygın engeller arasında kılavuzların net olmaması, kaliteli ve yeterli eğitimin olmaması, iş yükünün fazla olması, kaynakların ve desteğin az olması sıralanmaktadır. Doktorlar için ise, vurgulanan temel engeller arasında kanguru bakımının etkinliğinin anlaşılmaması, kabul edilmemesi ve yetersiz eğitimler belirtilmektedir. Ayrıca uygulama açısından yaşanan diğer engeller arasında, eğitim sonrası değerlendirme ve izlemenin olmaması, konunun üniversite müfredatı kapsamı dışında kalması ve kayıt tutma ile ilgili zorluklar yer almaktadır $^{14}$. Bu nedenle sağıı çalışanlarının bu konuda bilinçlendirilmesi sorunun büyük ölçüde çözülmesini sağlayabilir. Ayrıca annelere gebelik döneminde TTT'nin amacı, yararları ve nasıl uygulanması gerektiğine yönelik verilecek eğitimler ile annelerin bilgi düzeyini ve uygulamaları artabilir.

Araştırmamızda TTT kavramının kadınların yalnızca dörtte biri tarafından daha önceden bilindiği saptanmıştır. Kadınların TTT hakkındaki toplam bilgi puanın çok düşük olduğu (1.07 \pm 2.18$)$ belirlenmiştir Anneler TTT'nin anne ve bebek açısından yararları konusunda çoğunlukla annelik duygusunu artırdığı ve anne bebek bağlanmasını güçlendirdiği üzerinde durmuşlardır. Yılmaz Esencan ve arkadaşlarının (2018) yürüttükleri araştırmada kadınların \%12.2'sinin TTT ile ilgili bilgiyi doğuma hazırlık eğitimi sırasında öğrendikleri belirlenmiştir ${ }^{15}$. Uganda'da annelerin doğum sonu TTT konusundaki algılarını tanımlamak amacıyla yapılan kalitatif bir araştırmada TTT kavramını duyan ve yararlarının farkında olan bir gruba karşılık, konu hakkında bilgisi olmayan kadınların da bulunduğu belirtilmektedir. Kadınların bilgi ve algılarının kültürel, sosyal ve ekonomik farklılıklardan etkilendiği ifade edilmektedir ${ }^{21}$. Etkili ve kaliteli bir doğum öncesi bakım alamayan kadınlar doğum sürecinde ve sonrasında yapılan uygulamalar konusunda yetersiz kalabilirler. Bu nedenle kadınların TTT konusunda bilgilerinin olmadığı düşünülmektedir.

Araştırmada primipar gebelerin TTT uygulamasının gerçekleştirilmesinde anlamlı düzeyde başarılı oldukları saptanmıştır. Ancak Bedaso ve arkadaşlarının yapmışolduğu araştırmada paritenin TTT uygulamasının gerçekleştirilmesinde bir etkisinin olmadığı belirtilmiştir ${ }^{17}$. $\mathrm{Bu}$ durum kadınların kişisel özelliklerine göre değişiklik gösterebilmektedir. Annelik deneyimini ilk kez yaşayan kadınların bazıları doğru bilgiye erişimde daha ısrarcı olurken bazıları anne, abla, arkadaş deneyimlerinden yararlanarak kısa yoldan bilgiye ulaşmayı tercih edebilir. Sonuçların farklı olması bu nedenlerden kaynaklanabilir.

Mevcut araştırmada bilgi puanı yüksek kadınlarda TTT uygulamasının daha yüksek oranda olduğu belirlenmiştir. Uygulama hakkında daha fazla bilgiye sahip olan kadınların ten temasını sağlamada daha başarılı olması beklenen bir sonuçtur. Bu araştırmada kadınların eğitim durumu ile TTT uygulamasının gerçekleştirilmesi arasında anlamlı bir fark saptanmamıştır. Şaşırtıcı bir sonuç olarak Etiyopya da yürütülen araştırmada postpartum dönemde okuryazar olmayan kadınların ileri düzeyde eğitime sahip kadınlara göre 18 kat daha fazla TTT uygulamasını gerçekleştirdikleri belirlenmiştir ${ }^{17}$. Bu sonuçların gebelerin formal eğitimden çok aile üyeleri, yakın arkadaşlar gibi kaynaklar aracılığı ile edindikleri ve geleneksel uygulamalardan kaynaklandığı düşünülmektedir.

Mevcut araştırmada çalışan kadınlarda TTT uygulamasının anlamlı olarak daha yüksek oranda gerçekleştiği, sosyal güvencenin varlığının ise bu durumu etkilemediği saptanmıştır. Çalışan kadınların TTT uygulamasını daha yüksek oranda uygulamalarının nedeni, çalışan kadınların bilgiye erişim ve sosyal çevre ile etkileşimlerinin daha fazla olmasıyla açıklanabilir. Ancak kadınların gebelik dönemindeki eğitimlerde TTT hakkındaki bilgileri değerlendirilerek doğru ve güvenilir bilginin sağlanması oldukça önemlidir. Farklı sosyo-kültürel düzeydeki bireylerin geniş bir açıda ele alınması, doğru bilinen yanlışların saptanması ve doğru bilgiye ulaştırılması sağlık personelinin sorumluluğundadır. 
Tablo 4. Ten Tene Temas Uygulanma Durumunun Annelerin Tanıtıcı Özellikleri ve Obstetrik Özellikleri ile ilişsisi*

\begin{tabular}{|c|c|c|c|c|c|c|c|}
\hline \multirow[b]{2}{*}{ Özellikler } & \multicolumn{2}{|c|}{ Ten Tene Temas uygulanan } & \multicolumn{2}{|c|}{ Ten Tene Temas uygulanmayan } & \multicolumn{2}{|c|}{ Toplam } & \multirow[t]{2}{*}{$\mathbf{p}$} \\
\hline & $\mathbf{n}$ & $\%$ & $\mathbf{n}$ & $\%$ & & $\%$ & \\
\hline $\begin{array}{l}\text { Yaş } \\
18-29 \\
30-40\end{array}$ & $\begin{array}{l}7 \\
7\end{array}$ & $\begin{array}{l}50.0 \\
50.0\end{array}$ & $\begin{array}{l}56 \\
38\end{array}$ & $\begin{array}{l}59.6 \\
40.4\end{array}$ & $\begin{array}{l}63 \\
45\end{array}$ & $\begin{array}{l}58.3 \\
41.7\end{array}$ & 0.567 \\
\hline $\begin{array}{l}\text { Eğitim } \\
\text { İlköğretim } \\
\text { Orta öğretim ve üzeri }\end{array}$ & $\begin{array}{l}9 \\
5\end{array}$ & $\begin{array}{l}64.3 \\
35.7\end{array}$ & $\begin{array}{l}58 \\
36\end{array}$ & $\begin{array}{l}61.7 \\
38.3\end{array}$ & $\begin{array}{l}67 \\
41\end{array}$ & $\begin{array}{l}62.0 \\
38.0\end{array}$ & 0.853 \\
\hline $\begin{array}{l}\text { Çalışma Durumu } \\
\text { Çalışıyor } \\
\text { Çalış̧mıyor }\end{array}$ & $\begin{array}{l}6 \\
8\end{array}$ & $\begin{array}{l}42.9 \\
57.1\end{array}$ & $\begin{array}{c}8 \\
86\end{array}$ & $\begin{array}{c}8.5 \\
91.5\end{array}$ & $\begin{array}{l}14 \\
94\end{array}$ & $\begin{array}{l}13.0 \\
87.0\end{array}$ & 0.003 \\
\hline $\begin{array}{l}\text { Sosyal güvence } \\
\text { Var } \\
\text { Yok }\end{array}$ & $\begin{array}{l}12 \\
2\end{array}$ & $\begin{array}{l}85.7 \\
14.3\end{array}$ & $\begin{array}{l}75 \\
19\end{array}$ & $\begin{array}{l}79.8 \\
20.2\end{array}$ & $\begin{array}{l}87 \\
21\end{array}$ & $\begin{array}{l}80.6 \\
19.4\end{array}$ & 1.000 \\
\hline $\begin{array}{l}\text { Gebelik Sayısı } \\
\text { Bir } \\
\text { İki ve üstü }\end{array}$ & $\begin{array}{l}9 \\
5\end{array}$ & $\begin{array}{l}64.3 \\
35.7\end{array}$ & $\begin{array}{l}31 \\
63\end{array}$ & $\begin{array}{l}33.0 \\
67.0\end{array}$ & $\begin{array}{l}40 \\
68\end{array}$ & $\begin{array}{l}37.0 \\
63.0\end{array}$ & 0.024 \\
\hline $\begin{array}{l}\text { Doğum Sayısı } \\
\text { Bir } \\
\text { Iki ve üstü }\end{array}$ & $\begin{array}{l}9 \\
5\end{array}$ & $\begin{array}{l}64.3 \\
35.7\end{array}$ & $\begin{array}{l}44 \\
50\end{array}$ & $\begin{array}{l}46.8 \\
53.2\end{array}$ & $\begin{array}{l}53 \\
55\end{array}$ & $\begin{array}{l}49.0 \\
51.0\end{array}$ & 0.222 \\
\hline $\begin{array}{l}\text { Çocuk Sayısı } \\
\text { Bir } \\
\text { İki ve üstü }\end{array}$ & $\begin{array}{l}10 \\
4\end{array}$ & $\begin{array}{l}71.4 \\
28.6\end{array}$ & $\begin{array}{l}43 \\
51\end{array}$ & $\begin{array}{l}45.7 \\
54.3\end{array}$ & $\begin{array}{l}53 \\
55\end{array}$ & $\begin{array}{l}49.0 \\
51.0\end{array}$ & 0.073 \\
\hline $\begin{array}{l}\text { Toplam bilgi puanı } \\
0-5 \text { puan } \\
6-10 \text { puan }\end{array}$ & $\begin{array}{l}10 \\
4\end{array}$ & $\begin{array}{l}71.4 \\
28.6\end{array}$ & $\begin{array}{c}91 \\
3\end{array}$ & $\begin{array}{c}96.8 \\
3.2\end{array}$ & $\begin{array}{c}101 \\
7\end{array}$ & $\begin{array}{c}93.5 \\
6.5\end{array}$ & 0.005 \\
\hline $\begin{array}{l}\text { Ten tene teması } \\
\text { Duyan } \\
\text { Duymayan }\end{array}$ & $\begin{array}{l}5 \\
9\end{array}$ & $\begin{array}{l}35.7 \\
64.3\end{array}$ & $\begin{array}{l}22 \\
72\end{array}$ & $\begin{array}{l}23.4 \\
76.6\end{array}$ & $\begin{array}{l}27 \\
81\end{array}$ & $\begin{array}{l}25.0 \\
75.0\end{array}$ & 0.333 \\
\hline Toplam & 14 & 100.0 & 94 & 100.0 & 108 & 100 & \\
\hline
\end{tabular}

*Değişkenler arasındaki ilişkilerin değerlendirilmesi için Fisher's Exact Test kullanılmışır. 


\section{SONUÇ ve ÖNERILER}

Kadınların TTT konusunda yetersiz bilgiye sahip oldukları belirlenmiştir. Sağlık çalışanları, annelerin konuya ilişkin bilgi eksikliği sorunu olabileceği konusunda duyarlı olmalı, annelerin TTT konusunda doğru bilgilerini desteklemeli, eksik bilgilerini tamamlamalıdırlar. Ayrıca kadınların çok azının TTT uyguladıkları belirlenmiştir. Bunun nedenlerinin, bilgi eksikliği, sağlık çalışanlarının hatalı uygulamaları ve destek eksikliği olduğu belirlenmiştir. Gebelerin bilgilendirmesi ve doğumda sağlık çalışanlarından TTT uygulamasını talep etmeleri konusunda cesaretlendirilmeleri önemlidir. Ayrıca sağlık çalışanlarının farkındalığını ve duyarlılığını arttırmaya yönelik eğitimler ve protokoller hazırlanmalıdır. Konuya ilişkin sağılı çalışanları ve anneler ile kalitatif araştırmalar yapılarak engeller araştırımalıdır. Kalitatif araştırmalardan elde edilen sonuçlar eğitim ve protokol içeriklerinin oluşturulmasına katkı sağlayacaktır.

Etik Kurul Onayı: Dokuz Eylül Üniversitesi Girişimsel Olmayan Araştırmalar Değerlendirme Komisyonu'ndan 11.08.2016 tarih ve 2474-GOA protokol numaralı 2016/2328 karar numarası

Çıkar Çatışması: Yoktur.

Finansal Destek: Bildirilmemiştir.

Katılımcı Onamı: Katılımcılardan sözlü ve yazılı onam

alınmıştır.

Yazar katkıları:

Araştırma dizaynı: SM, BG, NNAA

Veri toplama: BG, NNAA

Literatür araştırması: SM, BG,NNAA

Makale yazımı: SM, BG, NNAA

Teşekkür

Yazarlar araştırmaya katılmayı kabul eden tüm kadınlara teşekkürlerini sunar.

Ethics Committee Approval: Approval was obtained from Non-interventional Clinical Research Ethics Committee of Dokuz Eylul University (Decision number: 2016/23-28).

Confict of Interest: Not reported.

Funding: None.

Exhibitor Consent: Informed consent was obtained from women.

Author contributions:

Study design: SM, BG, NNAA

Data collection: $B G$, NNAA

Literature search: SM, BG,NNAA

Drafting manuscript: SM, BG, NNAA

Acknowledgement: We would like to thank all women who approved to participate to the study.

\section{KAYNAKLAR}

1. National Institute for Health and Care Excellence (NICE). Quality statement 7: Skin-to-skin contact. Quality standard Published: 10 December 2017:26. nice.org.uk/guidance/qs105.

2. Association of Women's Health, Obstetric and Neonatal Nurses (AWHONN). Immediate and sustained skin-to-skin contact for the healthy term newborn after birth: AWHONN practice brief number 5. JOGNN 2016;45(6):842-44.

3. World Health Organization (WHO). WHO recommendations: Intrapartum care for a positive childbirth experience 2018:3-7.

4. Güleşen A, Yıldız D. Erken Postpartum dönemde anne bebek bağlanmasının kanıta dayalı uygulamalar ile incelenmesi. TAF Prev Med Bull. 2013;12(2):177-82.

5. Heinemann AB, Hellstrom-Westas L, HedbergNyqvist K. Factor saffecting parents' presence with their extremely preterm infants in a neonatal intensive care room. Acta Paediatrica 2013;102(7):695-702.

6. Leonard A, Mayers P. Parents' lived experience of providing kangaroo care to their preterm infants. Health SA Gesondheid. 2008;13(4):16-28.

7. Finigan V, Davies S. 'I just wanted to love, hold him forever': Women's lived experience of skin-to-skin contact with their baby immediately after birth. Evidence Based Midwifery. 2004;2(2):59-65.

8. Buckley SJ. Hormonal Physiology of Childbearing: Evidence and implications for women, babies, and maternity care. National Partnership for Women \& Families. 2015:6.

9. Moore ER, Bergman N, Anderson GC, Medley N. Early skin-to-skin contact for mothers and their healthy newborn infants. Cochrane Database of SystematicReviews 2016;11.

10. Cangöl E, Hotun Şahin N. Emzirmeyi etkileyen faktörler ve emzirme danışmanlığı. Zeynep Kamil Tıp Bülteni. 2014;45:100-05.

11. Çetinkaya $\mathrm{E}$, Ertem $\mathrm{G}$. Ten tene temasın anne-preterm bebek üzerine etkileri: Sistematik inceleme. Hemşirelikte Eğitim ve Araştırma Dergisi. 2017;14(2):167-75.

12. Ruiz-Peláez JG, Charpak N, Cuervo LG. Kangaroo Mother Care, an example to follow from developing countries. BMJ. 2004; 329(7475):1179-81.

13. Moran-Peters JA, Zauderer CR, Goldman S, Baierlein J, Smith AE. A quality improvement project focused on women's perceptions of skin to-skin contact after cesarean birth. Nurs Womens Health. 2014;18(4):294303.

14. Cattaneo A, Amani A, Charpak N, De Leon-Mendoza S, Moxon S, Nimbalkar S et al. Report on an international workshop on kangaroo mother care: Lessons learned and a vision for the future. BMC Pregnancy and Childbirth. 2018;18:170.

15. Yılmaz Esencan T, Karabulut Ö, Demir Yıldırım A, Ertuğrul Abbasoğlu $D$, Külek $H$, şimşek Ç ve ark. Doğuma Hazırlık eğitimi alan gebelerin doğum şekli, ilk emzirme zamanı ve ten tene temas tercihleri. Florence Nightingale Hemşirelik Dergisi. 2018;26(1):31-43.

16. Stevens J, Schmied V, Burns E, Dahlen H. A juxtaposition of birth and surgery: providing skin-toskin contact in the operating theatre and recovery. Midwifery. 2016;37:41-8.

17. Bedaso A, Kebede E, Adamu T. Assessment of skin-toskin contact (SSC) during the postpartum stay and its 
determinant factors among mothers at public health institutions in Ethiopia. BMC Res Notes. 2019;12:136.

18. Sever M. "Kadınlık, annelik, gönüllü çocuksuzluk: Elisabeth Badinter'den Kadınlık mı Annelik mi?, Tina Miller'dan Annelik Duygusu: Mitler ve deneyimler ve Corinne Maier'den No Kid üzerinden bir karşılaştırmalı okuma çalışması". Fe Dergi. 2015;7(2):72-86.

19. Kaya Şenol D, Aslan E. Vajinal doğum sonrası perineal soğuk uygulamanın fiziksel aktivitelere etkisi. F.N. Hem. Derg. 2016; 24(3):133-42.

20. Swain J, Dahlen HG. Putting evidence into practice: A quality activity of proactive pain relief for postpartum perineal pain. Women and Birth. 2013;26(1):65-70.

21. Byaruhanga RN, Bergstrom A, Tibemanya J, Nakitto C, Okong P. Perceptions among post-delivery mothers of skin-to-skin contact and newborn baby care in a periurban hospital in Uganda. Midwiferyi 2008;24(2):183-89.

22. Alenchery AJ, Thoppil J, Britto CD, de Onis JV, Fernandez L, Rao PNS. Barriers and enablers to skin-toskin contact at birth in healthy neonates - a qualitative study. BMC Pediatrics. 2018;18:48. 